\title{
TRAKTOWANIE PANDEMII WYWOLANEJ CHOROBĄ COVID-19 JAKO SILY WYŻSZEJ W KONTEKŚCIE ZOBOWIĄZAŃ UMOWNYCH ORAZ BIEGU TERMINU PRZEDAWNIENIA W POLSKIM PRAWIE CYWILNYM
}

\begin{abstract}
Streszczenie. Celem niniejszego opracowania jest wskazanie, czy obecnie panująca pandemia, związana z chorobą wywołaną przez wirus SARS-CoV-2, może być uznana na gruncie prawa cywilnego jako zdarzenie siły wyższej w kontekście zobowiązań umownych. Konieczne więc będzie rozważenie, czym jest siła wyższa w rozumieniu prawa cywilnego i jakie przesłanki muszą być spełnione, aby dane zdarzenie można było uznać za siłę wyższą. Nie ulega bowiem wątpliwości, że pandemia COVID-19 wywarła ogromny wpływ na obrót gospodarczy. Uzasadnione więc jest pytanie, czy pandemia ta może być traktowana jako siła wyższa uzasadniająca zwolnienie z odpowiedzialności za niewykonanie zobowiązania bądź zawieszenie biegu terminu przedawnienia w związku z niemożnością dochodzenia roszczeń w czasie jej trwania. Należy jednak zaznaczyć, iż opracowanie ma charakter ogólny i nie dotyczy rozwiązań szczegółowych.
\end{abstract}

Słowa kluczowe: siła wyższa, pandemia COVID-19, zobowiązanie umowne, niewykonanie zobowiązania, odpowiedzialność.

\section{COVID-19 AS A FORCE MAJEURE IN THE CONTEXT OF CONTRACTUAL OBLIGATIONS}

\begin{abstract}
The aim of this article is to indicate whether the current pandemic related to the disease caused by the SARS-CoV-2 virus can be recognised from a legal perspectice in the context of contractual obligations. It is essential to consider what force majeure is within the meaning of the civil law and what premises have to be fulfil to recognise the unforeseen circumstance as force majeure. The COVID-19 pandemic exerted, without a doubt, a huge influence on economic turnover. Here comes up a question whether this pandemic can be treated as force majeure justifying an exemption from liability for non-permormance of an obligation or suspension of the time-limit for the period of limitation in connection with an impossibility of prosecution of claims during the pandemic. It should be pointed out that the article is general and it does not involve detailed solutions.
\end{abstract}

Keywords: force majeure, COVID-19 pandemic, contractual obligation, non-performance of an obligation, liability.

\footnotetext{
*Uniwersytet Łódzki, Wydział Prawa i Administracji, kamila.kozien@edu.uni.lodz.pl
} 


\section{WSTĘP}

Kiedy w marcu 2020 roku wprowadzono w Polsce stan epidemii w związku z pandemią wywołaną chorobą COVID-19, raczej nikt nie spodziewał się, że stan ten utrzyma się aż tak długo. Od ponad roku tkwimy w owym stanie, doświadczając różnego rodzaju ograniczeń i obostrzeń, których celem jest ochrona życia i zdrowia obywateli. Niewątpliwie jednak, stan ten wpłynął również w istotnym stopniu na sferę gospodarczą i prawną w naszym kraju. Ograniczenia wywołane rozprzestrzeniającą się chorobą COVID-19 wielokrotnie uniemożliwiły wywiązanie się przez podmioty prywatne, publiczne, w tym w dużej mierze przez przedsiębiorców, ze zobowiązań. Co więcej, niejednokrotnie strony różnego rodzaju stosunków prawnych nie mogły dochodzić swych praw i roszczeń na drodze sądowej $\mathrm{z}$ uwagi na wprowadzane ograniczenia w przemieszczaniu się, ograniczoną pracę sądów czy niemożność dotarcia do sądu z uwagi na izolację i zakaz opuszczania miejsca pobytu w związku z odbywaną kwarantanną związaną z zakażeniem czy podejrzeniem zakażenia wirusem SARS-CoV-2.

W związku z powyższym, celem niniejszego artykułu będzie zastanowienie się, czy obecnie panująca pandemia związana z chorobą wywołaną przez wirus SARS-CoV-2 może być uznana na gruncie prawa cywilnego za zdarzenie siły wyższej, uzasadniającej zwolnienie z odpowiedzialności za niewykonanie zobowiązania bądź zawieszenie biegu terminu przedawnienia w związku z niemożnością dochodzenia roszczeń w czasie jej trwania. Aby móc odpowiedzieć na tak sformułowane pytanie, niezbędne jest rozważenie, czym jest siła wyższa w rozumieniu prawa cywilnego i jakie przesłanki muszą być spełnione, aby dane zdarzenie można było uznać za siłę wyższą. Problematyce tej poświęcone będą niniejsze rozważania, jednakże zaznaczyć należy, iż artykuł ten ma charakter ogólny i nie dotyczy rozwiązań szczegółowych.

\section{POJECIE „SILY WYŻSZEJ” W POLSKIM PRAWIE CYWILNYM}

Pojęcie „siły wyższej” nie zostało zdefiniowane przez polski Kodeks cywilny, nie ma więc jego legalnej definicji. Jednak znajdziemy w kodeksie przepisy, które wprost odwołują się do tego zjawiska, jak chociażby art. 121 pkt 4 ustawy z dnia 23 kwietnia 1964 r. - Kodeks cywilny (tekst jedn.: Dz.U. z 2020 r., poz. 1740 ze zm.), dotyczący instytucji zawieszenia biegu terminu przedawnienia co do roszczeń, gdy z powodu siły wyższej uprawniony nie może ich dochodzić przed sądem lub innym organem powołanym do rozpoznawania spraw danego rodzaju - przez czas trwania przeszkody.

Mimo braku definicji legalnej, pojęcie „siły wyższej” możemy zdefiniować powołując się zarówno na poglądy doktryny, jak również orzecznictwo. 
Odwołując się do poglądów doktryny prawa prywatnego należy wskazać, iż wypracowane zostały dwie teorie dotyczące rozumienia pojęcia siły wyższej: teoria subiektywna, której twórcą jest L. Goldschmidt i teoria obiektywna, autorstwa A. Exnera. Teoria subiektywna zakłada, że siłą wyższą są zjawiska, którym nie można zapobiec nawet przy dołożeniu należytej staranności, teoria obiektywna zaś zakłada, że kryterium wyróżniającym jest kwalifikacja samego zdarzenia, a nie stopień staranności działającego człowieka (CIC Kancelaria, Czajka-Marchlewicz, Dorska 2011). W prawie polskim powszechnie przyjmuje się obiektywne ujęcie siły wyższej, a więc uznaje się, iż jest ona zdarzeniem zewnętrznym, którego nie da się przewidzieć, ani też - nawet w razie przewidzenia - nie da się zapobiec jego skutkom (Pyziak-Szafnicka 2014). Zgodnie z tą koncepcją, za siłę wyższą będzie można więc uznać zdarzenie, które charakteryzuje się tym, że jest:

1) zewnętrzne;

2) niemożliwe do przewidzenia;

3) niemożliwe do zapobieżenia ${ }^{1}$.

Do takiej koncepcji siły wyższej przychyla się również orzecznictwo. Sąd Apelacyjny w Warszawie w wyroku z dnia 28 maja 2014 r. (I ACa 1775/13, LEX Nr 1489180) przyjął, że „siłę wyższą definiuje się jako zdarzenie zewnętrzne, którego nie można przewidzieć bądź mu zapobiec". Również Sąd Apelacyjny w Lublinie w wyroku z dnia 19 listopada 2019 r. (III APa 15/19, LEX Nr 2750252) wskazał, iż „za siłę wyższą jest uznawane wyłącznie zdarzenie charakteryzujące się trzema następującymi cechami: zewnętrznością, niemożliwością jego przewidzenia oraz niemożliwością zapobieżenia jego skutkom". Ujęcie obiektywne siły wyższej potwierdza także orzecznictwo Sądu Najwyższego, w którym podkreśla się, że siła wyższa rozumiana jest jako

zdarzenie zewnętrzne [...], o charakterze nadzwyczajnym, przejawiającym się w nieznacznym stopniu prawdopodobieństwa jego wystąpienia oraz o charakterze przemożnym, polegającym na niemożności jego „opanowania” i zapobieżenia jego skutkom na istniejącym w danej chwili poziomie rozwoju wiedzy i techniki. Zwykle przejawem tak rozumianej vis maior sq katastrofy żywiołowe - trzęsienia ziemi, powodzie lub huragany. Za siłę wyższą mogą być także uznane zdarzenia wywołane przez człowieka, jak działania wojenne lub gwałtowne rozruchy, a także akty władzy publicznej, którym należy się podporządkować pod groźbą sankcji. (Wyrok SN z dnia 21 maja 2019 r., IV CSK 129/18, LEX Nr 2690186)

Można więc zauważyć, że SN dokonał podziału zjawisk, które możemy uznać za siłę wyższą, na trzy grupy:

1) klęski żywiołowe (vis naturalis);

2) działania zbrojne (vis armata);

3) akty władzy (vis imperii) $)^{2}$.

\footnotetext{
${ }^{1}$ Tak samo stwierdzają: Cempura, Kasolik (2014).

${ }^{2}$ Takie same grupy wyszczególnia Parafianowicz (2020).
} 
Do pierwszej grupy zaliczyć możemy takie zjawiska, jak powódź, burza o ogromnej sile, huragan, nieprzenikniona mgła. Wśród zjawisk zaliczanych do drugiej grupy możemy wyróżnić: działania sił zbrojnych wrogiego państwa, rozruchy, rebelie i wojny domowe. Do trzeciej grupy należą zaś m.in. akty normatywne zakazujące wwozu określonych towarów lub decyzje administracyjne o zniszczeniu ładunku ze względów sanitarnych (Sendrowski 2020).

Powyższy katalog zjawisk, które możemy potraktować jako siłę wyższą, zaprezentowany przez SN i potwierdzany przez doktrynę, ma charakter jedynie przykładowy. Wyczerpujące wyliczenie przypadków, które można zakwalifikować do kategorii siły wyższej, nie jest możliwe (Pałdyna 2010). Nie da się bowiem przewidzieć wszystkich sytuacji i zjawisk, które mogłyby spełniać przesłanki siły wyższej - zawsze może się pojawić zjawisko, które do tej pory nie było rozważane pod kątem siły wyższej. Takim zjawiskiem, w moim przekonaniu, może być obecnie rozprzestrzeniająca się pandemia COVID-19, która bez wątpienia ma ogromny wpływ na funkcjonowanie obrotu cywilnoprawnego i gospodarczego, a przede wszystkim na wykonywanie zaciągniętych (zwłaszcza przed jej wystąpieniem) zobowiązań. W związku z powyższym, należy przyjrzeć się pandemii COVID-19 pod kątem przesłanek siły wyższej, co znajdzie wyraz w dalszej części opracowania.

\section{ROZUMIENIE SILY WYŻSZEJ W ORZECZNICTWIE UNIJNYM}

Zanim przejdę do szczegółowych rozważań dotyczących pandemii COVID-19 w kontekście siły wyższej, warto również zwrócić uwagę na rozumienie pojęcia siły wyższej na gruncie prawa europejskiego. Należy bowiem pamiętać, że w związku z członkostwem Rzeczpospolitej w Unii Europejskiej, prawo unijne stanowi część polskiego porządku prawnego, a co więcej ma pierwszeństwo stosowania przed polskimi ustawami. Istotne jest również orzecznictwo Trybunału Sprawiedliwości Unii Europejskiej, które może stanowić swego rodzaju wskazówkę dla judykatur krajowych co do tego, jak należy definiować dane pojęcie, czy jak traktować określone zjawisko. Jednakże, co trzeba podkreślić, jeśli w orzecznictwie TSUE zostaną sformułowane generalno-abstrakcyjne reguły (ewentualnie stojące za nimi bardziej ogólne zasady), to będą one dla sądów krajowych w sposób prawny wiążące (Koszowski 2012, 35-54).

Jeżeli chodzi o pojęcie ,siły wyższej”, to podobnie, jak w przypadku prawa polskiego, na gruncie prawa europejskiego pojęcie to pojawia się w wielu aktach prawa wtórnego UE, natomiast nie jest ono jednoznacznie zdefiniowane (Kastelik-Smaza 2020, 30-41). Pomocne w jego zrozumieniu może być orzecznictwo TSUE, w ramach którego wskazuje się, że pojęcie „siły wyższej”

obejmuje, poza obiektywnym elementem dotyczącym nadzwyczajnych i leżących poza sferą zainteresowanego okoliczności, element subiektywny polegający na obowiązku zabezpieczenia się przez zainteresowanego przed skutkami nadzwyczajnych zdarzeń poprzez 
przedsięwzięcie odpowiednich środków bez konieczności nadmiernych poświęceń. (Postanowienie TSUE z dnia 18 stycznia 2005 r., C-325/03, ECLI:EU:C:2005:28)

Zgodnie z utrwalonym orzecznictwem TSUE, pojęcie siły wyższej obejmuje zarówno element obiektywny, dotyczący nadzwyczajnych i niezależnych od zainteresowanego podmiotu okoliczności, jak i element subiektywny, odnoszący się do obowiązku dołożenia przez podmiot zainteresowany należytej staranności w celu zabezpieczenia się przed skutkami owych nadzwyczajnych okoliczności ${ }^{3}$. Niemożliwość przeprowadzenia danej czynności z uwagi na te nadzwyczajne okoliczności nie jest interpretowana przez TSUE jako niemożliwość bezwzględna - chodzi tu o swego rodzaju nietypowe, szczególne trudności, nieprzewidywalne okoliczności, które pozostają poza kontrolą danego podmiotu, pozostając od niego niezależnymi, których konsekwencji podmiot nie mógł uniknąć, nawet przy dołożeniu należytej staranności (Kastelik-Smaza 2020, 30-41; Ostałowski 2020).

Ciężar dowodu w postaci wykazania, iż w danym przypadku miało miejsce zdarzenie, które należy traktować jako siłę wyższą, spoczywa na podmiocie, który się na to zjawisko powołuje ${ }^{4}$. Jeżeli więc dany podmiot nie wykonał zobowiązania z uwagi na zdarzenie siły wyższej, to aby zwolnić się z odpowiedzialności za niewykonanie tego zobowiązania, będzie on musiał wpierw wykazać, iż taka siła wyższa w postaci zdarzenia nagłego, nadzwyczajnego miała miejsce, a co więcej, podmiot ten nie mógł zapobiec jej skutkom, nawet przy dołożeniu należytej staranności. Zwracał na to również uwagę rzecznik generalny UE Jacobs w opinii C-236/99, Komisja przeciwko Belgii z dnia 16 marca 2000 r., wskazując, że siła wyższa będzie skutkować zwolnieniem danej osoby z jej prawnego obowiązku, jeśli ta niemożliwa do przewidzenia zmiana okoliczności uczyniła niemożliwym wypełnienie tego obowiązku. Podobnie ma się sytuacja również w przypadku, gdy przykładowo państwo członkowskie nie wykonuje zobowiązań traktatowych, wówczas państwo może się zwolnić z odpowiedzialności z tego tytułu, tylko jeżeli wykaże, iż niemożność wykonania takiego zobowiązania była wynikiem wystąpienia nadzwyczajnych okoliczności, nieprzewidywalnych, niezależnych od jego woli - a więc gdy miała miejsce siła wyższa (Sikora 2011).

Podsumowując, definicja pojęcia „siły wyższej”, wypracowana na gruncie prawa europejskiego przez orzecznictwo TSUE, niewiele różni się od definicji wypracowanej przez doktrynę i orzecznictwo $\mathrm{w}$ ramach polskiego porządku prawnego. To, co jest warte podkreślenia, to fakt, że na gruncie prawa europejskiego bardzo wyraźnie akcentuje się element subiektywny, mieszczący się w pojęciu ,siły wyższej”, który związany jest z obowiązkiem dochowania należytej staranności przez podmiot, który powołuje się na siłę wyższą, a więc z koniecznością wykazania przez ten podmiot, iż nie był on w stanie wykonać ciążącego na nim obowiązku poprzez wykorzystanie właściwych środków, bez nadmiernego poświęcenia.

\footnotetext{
${ }^{3}$ Zwraca na to uwagę Kastelik-Smaza (2020, 30-41).

${ }^{4}$ Ibidem.
} 
Biorąc to pod uwagę, w dalszej części opracowania konieczne jest zastanowienie się, czy podmiot powołujący się na siłę wyższą w postaci pandemii COVID-19 (jeżeli oczywiście zaliczymy pandemię do zdarzenia siły wyższej) będzie mógł zwolnić się z odpowiedzialności z tytułu niewykonania zobowiązania $\mathrm{z}$ uwagi na fakt, iż nie był on w stanie zapobiec skutkom tego zdarzenia, mimo dochowania należytej staranności, a także, czy również w innych przypadkach może się okazać zasadne powołanie się na pandemię COVID-19 jako na siłę wyższą.

\section{PANDEMIA COVID-19 A SILA WYŻSZA}

Bez wątpienia obecnie występująca pandemia COVID-19 jest zjawiskiem, które wywołało ogromny wpływ na obrót gospodarczy i stosunki cywilnoprawne. $\mathrm{Z}$ uwagi na tę pandemię wiele podmiotów nie mogło wykonać ciążących na nich obowiązków, a w przypadku wielu przedsiębiorstw doszło do znacznego spadku obrotów lub nawet całkowitego zawieszenia prowadzenia działalności gospodarczej. Również w kontekście postępowań sądowych nieustępująca pandemia przyczyniła się do tego, że sądy znacznie ograniczyły swoją działalność, co więcej, $\mathrm{z}$ uwagi na wprowadzane ograniczenia $\mathrm{w}$ przemieszczaniu się, czy przypadki poddania się przymusowej kwarantannie, obywatele niejednokrotnie nie mogli dochodzić swoich praw przed sądem, na co nie mieli żadnego wpływu. W związku z powyższym, należy zastanowić się, czy z uwagi na te wszystkie skutki, jakie pociągnęła za sobą pandemia COVID-19, należy kwalifikować ją jako siłę wyższą uzasadniającą zwolnienie z odpowiedzialności za niewykonanie zobowiązania czy zawieszenie biegu terminu przedawnienia w związku z niemożnością dochodzenia przed sądem bądź innym organem swoich roszczeń przez podmiot uprawniony.

Jak podkreśla się w doktrynie, generalnie można przyjąć, iż pandemia COVID-19 spełnia przesłanki siły wyższej, w związku z czym można mówić w jej przypadku o działaniu siły wyższej - posiada bowiem wszystkie cechy, które wskazuje się w polskim orzecznictwie poświęconym pojęciu siły wyższej, a mianowicie jest to zdarzenie nadzwyczajne o nadzwyczajnych konsekwencjach, niemożliwe do przewidzenia, a ponadto ze względu na moc oddziaływania tego zdarzenia, nie można było skutecznie bronić się przed jego skutkami (Sendrowski 2020). Pandemia COVID-19 może być również objęta pojęciem siły wyższej wypracowanym przez orzecznictwo TSUE, gdyż jest to zdarzenie o charakterze zewnętrznym, niemożliwe do przewidzenia, niezależne od państw członkowskich i podmiotów, a ponadto $\mathrm{w}$ wielu przypadkach podmioty powołujące się na siłę wyższą nie były w stanie zapobiec skutkom pandemii pomimo dołożenia należytej staranności (Kastelik-Smaza 2020, 30-41). Z uwagi na to można by uznać, że nie ma przeszkód co do tego, by powoływać się w przypadku COVID-19 na siłę wyższą. W praktyce jednak taka ogólna konstrukcja nie oznacza, że w stosunku 
do pandemii koronawirusa zawsze będzie można powołać się na siłę wyższą. Organy, które rozstrzygają, czy w danym przypadku pandemia może zostać uznana za siłę wyższą, powinny podejmować decyzję w każdej sprawie indywidualnie, na podstawie towarzyszących jej okoliczności i stosownych dowodów (Kastelik-Smaza 2020, 30-41).

W dalszej części zostaną omówione poszczególne sfery, na które wpływ mogła mieć pandemia koronawirusa, w celu wskazania, czy w danym przypadku możemy mówić o wystąpieniu zdarzenia siły wyższej, czy też nie.

\subsection{COVID-19 a zobowiązania umowne}

W pierwszej części należy przyjrzeć się przypadkom niewykonania zobowiązań, wynikających z umów z uwagi na ograniczenia związane z pandemią COVID-19. Dla zwolnienia się z odpowiedzialności za niewykonanie zobowiązania poprzez powołanie się na siłę wyższą konieczne jest wykazanie przez podmiot, który na zjawisko siły wyższej się powołuje, że rzeczywiście ono wystąpiło, a co więcej zaistniał związek przyczynowy pomiędzy zdarzeniem siły wyższej a niewykonaniem zobowiązania (Kastelik-Smaza 2020, 30-41). Ponadto, wykazanie samego elementu obiektywnego nie wystarczy, musi bowiem jeszcze zaistnieć element subiektywny. Podmiot zainteresowany musi wykazać, że podjął wszelkie możliwe środki, które miały na celu zapobieżenie skutkom siły wyższej, lecz $\mathrm{z}$ uwagi na nadzwyczajny charakter tego zdarzenia nie był w stanie im zapobiec (Kastelik-Smaza 2020, 30-41).

A. Kastelik-Smaza wskazuje, że w przypadku umów takimi środkami mogą być przykładowo: renegocjacja warunków umowy, w tym terminów wykonania zobowiązania, jak również poinformowanie kontrahenta o zaistnieniu zdarzenia siły wyższej. Należy jednak zwrócić uwagę na fakt, że zupełnie inna sytuacja będzie miała miejsce w przypadku umów zawartych przed wybuchem pandemii, a inna w przypadku umów zaciągniętych w trakcie jej trwania. Wydaje się bowiem, na co zwraca uwagę A. Kastelik-Smaza, że w przypadku zobowiązań zaciągniętych już po wybuchu pandemii, strony danej umowy powinny były przewidzieć istotne trudności, jakie mogą pojawić się przy wykonywaniu zobowiązania w związku z ograniczeniami, jakie zaczęto wprowadzać w celu przeciwdziałania skutkom pandemii COVID-19 i wobec tego ująć w umowie, w kalkulacji kosztów, jak również w ustalaniu terminów wykonania danej umowy, związane z tymi ograniczeniami trudności oraz potencjalne ryzyko niemożliwości wykonania zobowiązania (Kastelik-Smaza 2020, 30-41). To podejście jest jak najbardziej słuszne, jeżeli bowiem strony zawierają umowę po wybuchu pandemii, to mają już świadomość tego, jak pandemia i wprowadzane w związku z nią ograniczenia wpływają na wykonywanie zobowiązań, a zwłaszcza na terminowe ich wykonywanie, w związku z czym mogą, a nawet powinny dostosować postanowienia zawieranej umowy do realiów obrotu istniejących w okresie pandemii. 
Aby ocenić, czy w danym konkretnym przypadku można się skutecznie powołać na pandemię koronawirusa jako zdarzenie siły wyższej stanowiące okoliczność egzoneracyjną, czyli zwalniającą z odpowiedzialności, konieczne jest również przeanalizowanie zawartej między stronami umowy. Przede wszystkim należy szczegółowo przeanalizować i zweryfikować treść wprowadzonych przez stronę do umowy klauzul odnoszących się do przypadków siły wyższej (Rawa 2020). Strony mogą bowiem w umowie wskazać, jak definiują siłę wyższą na potrzeby tej umowy i jaki wpływ na odpowiedzialność podmiotu zobowiązanego może mieć jej wystąpienie. Jak bowiem wskazuje chociażby Krajowa Izba Odwoławcza w wyroku z dnia 10 czerwca 2020 r. (KIO 631/20, LEX Nr 3029206):

umieszczenie $\mathrm{w}$ umowie klauzuli siły wyższej jest dopuszczalne zgodnie z art. $353^{1}$ k.c. Stosownie do zasady swobody umów zawartej w tym przepisie nie narusza prawa zdefiniowanie siły wyższej szerzej, niż wynikałoby to z rozumienia tego określenia przyjętego powszechnie w doktrynie i orzecznictwie.

Strony mogą więc samodzielnie umówić się co do tego, jakie zjawiska traktować będą jako siłę wyższą i jak, w przypadku ich wystąpienia, będzie wyglądać kwestia dalszej współpracy stron oraz ich odpowiedzialności z tytułu niewykonania zobowiązania (Sendrowski 2020). Należy jednak pamiętać, że z reguły, mimo wyodrębnienia w umowie katalogu zjawisk traktowanych jako siła wyższa, katalog ten nie będzie miał charakteru zamkniętego i prawdopodobnie nie znajdziemy w nim odwołania do zjawiska pandemii. Mimo to, możemy przyjąć za R. Gniezdzią z dużym prawdopodobieństwem, że okoliczności związane z sytuacją pandemii i wynikające z niej skutki można uznać za zjawiska objęte pojęciem siły wyższej, pod warunkiem, że strony nie zastrzegły inaczej (Gniezdzia 2020). Trzeba jednak również pamiętać, że strony mogą przewidzieć w umowie rozszerzoną odpowiedzialność dłużnika za niewykonanie zobowiązania, poprzez przyjęcie przez niego na siebie wszelkiego ryzyka niewykonania bądź nienależytego wykonania zobowiązania, w tym ryzyka związanego z wystąpieniem siły wyższej (Gniezdzia 2020). Taka sytuacja mieści się w dyspozycji art. $473 \S 1$ k.c., który będzie wówczas stanowił podstawę odpowiedzialności dłużnika w przypadku niewykonania bądź nienależytego wykonania zobowiązania. Podmiot zobowiązany będzie więc ponosił odpowiedzialność, nawet jeśli uznamy, że w danym przypadku należy potraktować pandemię COVID-19 jako siłę wyższą.

W odniesieniu do niektórych rodzajów umów mogą wystąpić szczególne rozwiązania związane z panującą pandemią. Przykładem może być umowa o imprezę turystyczną. W związku z ograniczeniami wprowadzanymi w celu zapobieżenia rozpowszechnianiu się pandemii koronawirusa, pojawił się problem realizacji zobowiązań wynikających z uprzednio zawartych umów o imprezę turystyczną. $\mathrm{Z}$ uwagi na zamknięcie granic i ograniczenia w przemieszczaniu się, umowy takie w wielu przypadkach nie mogły zostać zrealizowane. W związku z powyższym, stoję na stanowisku, że w takim przypadku organizator ma prawo powołać się 
na siłę wyższą, która będzie stanowić okoliczność wyłączającą jego odpowiedzialność za niewykonanie zobowiązania, z tym, że w tym przypadku będzie to siła wyższa w postaci nie tyle samej pandemii, co działań władzy, bowiem pojawia się tu niemożność wykonania zobowiązania ze względu na uchwalane przez organy państwowe akty prawne, mocą których wprowadzane są liczne ograniczenia w przemieszczaniu się i to zarówno wewnątrzkrajowym, jak i międzypaństwowym. Tutaj jednak pragnę zwrócić uwagę, że podobnie, jak w przypadku innych umów, należy inaczej podchodzić do umów zawartych przed wybuchem pandemii - wówczas wybuch pandemii należy traktować jako zdarzenie nadzwyczajne, podobnie jak wprowadzane przez władze w bardzo krótkim czasie ograniczenia w przemieszczaniu się, których bez wątpienia nie dało się wówczas przewidzieć, a inaczej w stosunku do umów, które zawarte zostały po wybuchu pandemii - tutaj powoływanie się na siłę wyższą nie powinno być skuteczne, gdyż należy oczekiwać, że w takim przypadku strony mogły przewidzieć - i to $\mathrm{z}$ dużym prawdopodobieństwem - iż może się okazać, że umowa nie będzie mogła być wykonana $z$ uwagi na wprowadzane ograniczenia.

Warto również zwrócić uwagę na pewne rozwiązania, które zostały wprowadzone w kontekście umów o imprezę turystyczną mocą ustawy z dnia 31 marca 2020 r. o zmianie ustawy o szczególnych rozwiązaniach związanych z zapobieganiem, przeciwdziałaniem i zwalczaniem COVID-19, innych chorób zakaźnych oraz wywołanych nimi sytuacji kryzysowych, oraz niektórych innych ustaw (Dz.U. poz. 568). Dodany mocą tej ustawy art. 15k ustawy z dnia 2 marca 2020 r. o szczególnych rozwiązaniach związanych z zapobieganiem, przeciwdziałaniem i zwalczaniem COVID-19, innych chorób zakaźnych oraz wywołanych nimi sytuacji kryzysowych stanowi, że odstąpienie od umowy w trybie określonym w art. 47 ust. 4 ustawy z dnia 24 listopada 2017 r. o imprezach turystycznych i powiązanych usługach turystycznych (tekst jedn.: Dz.U. 2020, poz. 2139) lub rozwiązanie przez organizatora turystyki umowy o udział w imprezie turystycznej w trybie określonym w art. 47 ust. 5 pkt 2 tej ustawy, które to odstąpienie lub rozwiązanie pozostaje $\mathrm{w}$ bezpośrednim związku z wybuchem epidemii wirusa SARS-CoV-2, jest skuteczne z mocy prawa po upływie 180 dni od dnia powiadomienia przez podróżnego o odstąpieniu od umowy lub powiadomienia o rozwiązaniu przez organizatora turystyki (tekst jedn.: Dz.U. 2020, poz. 1842 ze zm.). Jak wskazywano w uzasadnieniu do projektu ustawy z 31 marca 2020 r., to rozwiązanie miało dotyczyć umów, które zostały rozwiązane w bezpośrednim związku $\mathrm{z}$ wybuchem epidemii, a jego celem było

stworzenie możliwości na zorganizowanie odpowiednich kredytów pomostowych czy skorzystanie ze specjalnej pomocy państwa w celu zapewnienia płynności branży turystycznej. Alternatywnie klient może skorzystać z propozycji organizatora turystyki do otrzymania vouchera na realizację imprezy turystycznej w przyszłości, w ciągu roku od dnia, w którym miała się odbyć. [...] Przyjęcie przez klienta vouchera nie powoduje rozwiązania umowy z organizatorem turystyki, dlatego środki wpłacone przez klientów będą podlegały ochronie przed 
niewypłacalnością. Voucher ma umożliwić istotną zmianę warunków umowy między stronami poprzez wskazanie np. nowego miejsca destynacji, czasu odbycia podróży, itp. Dodatkowo, wpłacone środki nie będą traktowane jako nowe wpłaty klientów, stąd nie znajdzie zastosowania regulacja dotycząca przedpłat na poczet modyfikacji gwarancji ubezpieczeniowych, bankowych czy ubezpieczeń na rzecz klientów przez organizatorów turystyki. Vouchery dla klientów będą więc w pełni chronione i umożliwią sprawne przekładanie imprez turystycznych na korzystniejszych warunkach. (Druk Nr 299, 18)

Art. 15zp ustawy o szczególnych rozwiązaniach związanych z zapobieganiem, przeciwdziałaniem i zwalczaniem COVID-19, innych chorób zakaźnych oraz wywołanych nimi sytuacji kryzysowych stanowi natomiast, że przedsiębiorca, prowadzący działalność związaną z organizacją wystaw i kongresów lub działalność kulturalną, rozrywkową, rekreacyjną i sportową lub organizujący wystawy tematyczne czy imprezy plenerowe, w przypadku rozwiązania umowy z klientem, które to rozwiązanie umowy pozostaje w bezpośrednim związku z wybuchem epidemii wirusa SARS-CoV-2, jest zobowiązany zwrócić wpłacone mu przez klienta środki w terminie 180 dni od dnia skutecznego rozwiązania umowy. W uzasadnieniu projektu tej ustawy wskazano, że rozwiązanie to ma dać

duże możliwości w zachowaniu płynności finansowej w branżach wystawienniczych, kongresowych, branży rozrywkowej, sportowej i organizacji imprez i wystaw. Jednocześnie klient może wyrazić zgodę na pobranie vouchera $\mathrm{w}$ zamian za odstąpienie od rezygnacji $\mathrm{z}$ danej umowy. Voucher będzie podstawą do realizacji w ramach wydarzeń organizowanych przez danego organizatora w ciągu roku od dnia, w którym miało się odbyć pierwotne wydarzenie. Jednocześnie wartość vouchera nie może być niższa niż wysokość dotychczasowej wpłaty klienta. Zaproponowane regulacje powinny być stosowane odpowiednio w branży hotelarskiej, ale tylko wówczas, gdy odstąpienie od umowy jest rzeczywiście związane z wystąpieniem epidemii wirusa SARS-CoV-2. Wobec powyższego odstąpienie nie może opierać się na indywidualnym przeświadczeniu klienta, a powinno być poparte rzeczywistym związkiem przyczynowo-skutkowym. (Druk Nr 299, 43)

Te rozwiązania mają więc na celu powstrzymać niewypłacalność organizatorów, ale także zapewnić ochronę praw konsumentów, wobec czego można powiedzieć, że zachodzi tu słuszne wyważenie wzajemnych interesów stron (Stradomska-Balcerzyk 2020, 9).

$\mathrm{Na}$ sam koniec rozważań dotyczących możliwości powołania się na COVID-19 jako siłę wyższą, zwalniającą z odpowiedzialności za niewykonanie zobowiązania, warto zauważyć, że niekiedy również państwo będzie mogło zwolnić się z odpowiedzialności kontraktowej powołując się na siłę wyższą. Jednakże nie każdy przypadek niewykonania zobowiązania w warunkach rozprzestrzeniającej się pandemii można traktować jako wystąpienie zdarzenia siły wyższej, zwalniającego państwo z odpowiedzialności z tego tytułu. Każda sprawa powinna być rozpatrywana indywidualnie z uwzględnieniem zachodzących w niej okoliczności. W przypadku jednak, gdy uznamy, że wykonanie danego zobowiązania nie jest możliwe, na co wpływ miał wybuch pandemii COVID-19 lub związane z nim działania państwa, to należy dołożyć wszelkich starań, aby zastosowanie znalazły 
przepisy o niemożliwości świadczenia i sile wyższej (Zoll 2020, 255). Ponadto, gdy na skutek kryzysu związanego z pandemią COVID-19 i podjętych w związku z nim czynności, wykonanie zobowiązania stało się nadmiernie trudne, państwa powinny dołożyć starań, by renegocjować umowę, zgodnie z zasadami dobrej wiary (Zoll 2020, 255). Co więcej, w przypadku zaburzenia stosunków umownych, państwa powinny dołożyć także starań, by jego skutki nie dotknęły wyłącznie jednej ze stron, a zwłaszcza konsumenta czy małych i średnich przedsiębiorstw (Zoll 2020, 255).

Podsumowując; widać więc, że w przypadku niewykonania zobowiązań umownych nie zawsze będzie można skutecznie zwolnić się z odpowiedzialności poprzez powołanie się na wystąpienie siły wyższej w postaci COVID-19. W tym celu konieczne będzie wykazanie, iż w danym przypadku pandemia i jej konsekwencje spełniają przesłanki siły wyższej, zachodzi związek przyczynowy między tym zjawiskiem a niewykonaniem zobowiązania, a także dołożono wszelkich starań, by negatywnym skutkom takiego zdarzenia zapobiec. Co więcej, inaczej będziemy traktować zobowiązania zawarte przed wybuchem pandemii i te, które zawiązano już w trakcie jej trwania. Wynika z tego, że do każdego rozstrzyganego przypadku będzie należało podchodzić indywidualnie.

\subsection{COVID-19 a zawieszenie biegu terminu przedawnienia}

Pandemia COVID-19 niewątpliwie wpłynęła również na postępowania sądowe. Należy bowiem zauważyć, że działalność sądów, zwłaszcza w marcu, kiedy zaczęto wprowadzać różnego rodzaju obostrzenia, była w znacznym stopniu ograniczona. Co więcej, nawet w późniejszym okresie trwania pandemii powszechne były przypadki, gdy przykładowo strona nie mogła stawić się na rozprawie z uwagi na nałożony na nią obowiązek poddania się kwarantannie lub gdy sąd nie móg1 rozpoznać sprawy z uwagi na objęcie sędziów przymusową kwarantanną. Biorąc to pod uwagę, celem tej części opracowania będzie udzielenie odpowiedzi na pytanie, czy pandemia COVID-19 może być traktowana jako siła wyższa uzasadniająca zawieszenie biegu terminu przedawnienia, przewidziane w art. 121 pkt 4 k.c.

Na początku trzeba zwrócić uwagę, że zgodnie z - dodanym ww. ustawą zmieniającą z 31 marca 2020 r. - art. 15zzr ust. 1 pkt 3 ustawy o szczególnych rozwiązaniach związanych z zapobieganiem, przeciwdziałaniem i zwalczaniem COVID-19, innych chorób zakaźnych oraz wywołanych nimi sytuacji kryzysowych, w okresie obowiązywania stanu zagrożenia epidemicznego albo stanu epidemii z powodu COVID-19 bieg przewidzianych przepisami prawa administracyjnego terminów przedawnienia nie rozpoczyna się, a rozpoczęty ulega zawieszeniu na ten okres (tekst jedn.: Dz.U. 2020, poz. 1842 ze zm.). Ustawa milczy natomiast co do biegu terminów prawa cywilnego, podczas gdy projekt ustawy zmieniającej zakładał, że przepis będzie dotyczył zarówno biegu terminów przewidzianych w prawie administracyjnym, jak i cywilnym. W toku działań legislacyjnych 
usunięto jednak określenie odnoszące się do terminów prawa cywilnego. Jak wskazuje M. Strus-Wołos, część komentatorów wyciąga z tego wniosek, że ustawodawca nie zdecydował się na ingerencję w bieg terminów przedawnienia roszczeń cywilnoprawnych, a więc terminy te biegną dalej również w okresie obowiązywania pandemii, zwłaszcza że działalność sądów, mimo iż została dość mocno ograniczona, to jednak nie całkowicie zawieszona, w związku z czym nie ma podstaw do tego, by w przypadku pandemii mówić o wystąpieniu siły wyższej w rozumieniu art. 121 pkt 4 k.c. (Strus-Wołos 2020). Jak jednak zauważa powołana autorka, pojęcie „siły wyższej” rzadko występuje w przepisach prawa administracyjnego, a przede wszystkim nie pojawia się ono w kontekście biegu terminów przedawnienia, w związku z czym istniała konieczność wprowadzenia w ww. ustawie przepisu, który będzie wprowadzał zawieszenie biegu terminów prawa administracyjnego, w przeciwieństwie do biegu terminów przewidzianych w prawie cywilnym, gdyż te mają swoją własną regulację - w ramach art. 121 pkt 4 k.c. Błędem legislacyjnym byłoby więc odniesienie się w specustawie do tych terminów, gdyż nie ma potrzeby potwierdzania przepisem szczególnym możliwości zastosowania przepisu kodeksowego (Strus-Wołos 2020). Są jednak również odmienne głosy $\mathrm{w}$ doktrynie, $\mathrm{w}$ ramach których podkreśla się, że fakt, iż projekt ww. ustawy i ww. przepisu odwoływał się zarówno do terminów prawa administracyjnego, jak i prawa cywilnego, w sposób jednoznaczny i nie budzący wątpliwości wskazuje, że intencją ustawodawcy było zawieszenie biegu terminów zarówno prawa administracyjnego, jak również (a może przede wszystkim) terminów prawa cywilnego (Stradomska-Balcerzyk 2020, 5).

Za bardziej przekonujący należy uznać pogląd, że skoro ustawodawca zrezygnował z odwołania się w art. 15zzr ww. ustawy do terminów przewidzianych prawem cywilnym, to nie odnosi się on do tych terminów, a więc specustawa może być stosowana wyłącznie do biegu terminów prawa administracyjnego. Należy podzielić pogląd, iż skoro mamy przepis kodeksu cywilnego, przewidujący możliwość zawieszenia biegu terminu przedawnienia (terminu prawa cywilnego) z uwagi na wystąpienie siły wyższej, to nie ma potrzeby wprowadzania przepisu szczególnego w specustawie, który będzie przewidywał zawieszenie takich terminów w okresie pandemii. Zawieszenie biegu terminu przedawnienia prawa cywilnego z uwagi na pandemię COVID-19 może nastąpić na podstawie wyłącznie art. 121 pkt 4 k.c., gdyż pandemia koronawirusa może być uznana za siłę wyższą, uniemożliwiającą dochodzenie roszczeń przez okres jej trwania, o której mowa w przytoczonym przepisie. Pojawia się tu jednak pytanie, czy w każdym przypadku podmiot zainteresowany może się powoływać na pandemię COVID-19 jako siłę wyższą z art. 121 pkt 4 k.c., a więc czy przez cały czas trwania pandemii uzasadnia ona zawieszenie biegu terminów przedawnienia jako siła wyższa uniemożliwiająca dochodzenie roszczeń?

Odpowiadając na tak zadane pytanie należy zauważyć, że w żadnym momencie trwania pandemii nie zawieszono całkowicie działalności sądów. Owszem, 
została ona w znacznym stopniu ograniczona, jednak sądy nadal były dostępne dla stron, pełnomocników, sędziów i innych pracowników sądu, choć w ograniczonym zakresie (Partyk 2020, 42-52). Trzeba tu również zauważyć, że co prawda działalność biur podawczych w wielu sądach została zawieszona, ale w wielu sądach wystawiono jednocześnie specjalne skrzynki, do których można było składać wnoszone pisma. Ponadto, nie została również całkowicie zawieszona działalność operatora pocztowego - Poczty Polskiej, w związku z czym nie można mówić, że wyłączona została całkowicie możliwość wnoszenia pism procesowych. W tym kontekście niejednokrotnie zwraca się jednak uwagę na fakt wprowadzenia zakazu przemieszczania się mocą rozporządzeń Rady Ministrów w sprawie ustanowienia określonych ograniczeń, nakazów i zakazów w związku z wystąpieniem stanu epidemii - przykładowo z dnia 31 marca 2020 r. (Dz.U. 2020, poz. 566), z dnia 10 kwietnia 2020 r. (Dz.U. 2020, poz. 658) czy z dnia 2 maja 2020 r. (Dz.U. 2020, poz. 792). Od tego zakazu były jednak wyjątki, a mianowicie zakaz ten nie obejmował przykładowo przemieszczania się w związku z wykonywaniem czynności zawodowych lub zadań służbowych, a także w celu zaspokajania niezbędnych potrzeb, związanych z bieżącymi sprawami życia codziennego, na co zwraca również uwagę M. Strus-Wołos. W związku z powyższym wskazuje się, że w sytuacji, gdy strona działa przez pełnomocnika profesjonalnego i za jego pośrednictwem wnosi pisma do sądu, to takie przemieszczanie się adwokata czy radcy prawnego mieści się w wyjątku od zakazu przemieszczania, gdyż wykonuje on swoje czynności zawodowe. Wątpliwym jest natomiast zaliczenie przemieszczania się strony działającej bez pełnomocnika w celu wniesienia pisma procesowego do wyjątku od zakazu przemieszczania się - nie jest to bowiem w sposób oczywisty związane z wykonywaniem obowiązków zawodowych, a ponadto wątpliwe jest również to, aby takie przemieszczanie się mogło mieścić się w drugim dopuszczalnym wyjątku, tj. przemieszczania się w celu zaspokajania niezbędnych potrzeb związanych z bieżącymi sprawami życia codziennego, wobec czego podnosi się również, że dochodzi tu do zróżnicowania sytuacji prawnej strony korzystającej z pomocy profesjonalnego pełnomocnika i osoby działającej samodzielnie (Strus-Wołos 2020). Co więcej, część autorów podkreśla, że nie należy zmuszać ludzi, by w czasie pandemii udawali się na pocztę lub do biura podawczego sądu celem złożenia określonego pisma procesowego, zwłaszcza gdy same przepisy zakazują przemieszczania się poza określonymi przypadkami i to pod groźbą kar pieniężnych. Ponadto, zagrożenie zakażeniem koronawirusem jest na tyle powszechne, a ryzyko ciężkiego przebiegu choroby tak duże, że w okresie pandemii należy stosować prawo w sposób jednolity i powszechny, a co za tym idzie należy stosować art. 121 pkt 4 k.c. w każdym przypadku dochodzenia roszczeń przez czas trwania epidemii (Strus-Wołos 2020). W moim przekonaniu nie jest to jednak właściwe podejście. Przede wszystkim, o ile w początkowym czasie trwania pandemii, w związku z wprowadzanymi ograniczeniami, można rozważać zaistniałą sytuację jako siłę wyższą, o tyle już w czasie trwania pandemii, gdy te obostrzenia 
złagodzono, na sprawę trzeba spojrzeć z lekkim dystansem. Skoro bowiem sądy i Poczta Polska działały, a zakazy przemieszczania się złagodzono, to należy uznać, że w takim przypadku strona miała możliwość dochodzenia swych roszczeń. Oczywiście, sytuacja może się skomplikować, gdy strona przebywa na przymusowej kwarantannie.

Rozważając kwestię kwarantanny, należy zauważyć, że jeżeli dana osoba przebywa na kwarantannie na podstawie decyzji Sanepidu albo przebywa w placówce medycznej z uwagi na zarażenie wirusem SARS-CoV-2, to z oczywistych względów nie może ona samodzielnie dokonywać czynności prawnych czy procesowych, w związku z czym zachodzi wówczas podstawa do zawieszenia terminu przedawnienia w trybie art. 121 pkt 4 k.c. (Gołaczyński 2020, 4). Istotne jest jednak rozróżnienie przebywania w odosobnieniu w warunkach szpitalnych, kiedy dana osoba jest praktycznie pozbawiona kontaktu ze światem zewnętrznym, od kwarantanny odbywanej w warunkach domowych, gdzie jest możliwość skorzystania z komputera czy telefonu (Kania 2020). W przypadku bowiem kwarantanny domowej, dana osoba ma co do zasady możliwość porozumienia się z pełnomocnikiem. Taką sytuację również jednak należy oceniać w dwojaki sposób. Zauważa się bowiem, że przymusowa izolacja nie przesądza sama w sobie o niemożności złożenia pisma, z uwagi na możliwość złożenia pisma drogą elektroniczną czy za pośrednictwem ustanowionego przez daną osobę pełnomocnika. Odmiennie należy oceniać natomiast sytuację, kiedy strona jeszcze przed wszczęciem postępowania została objęta obowiązkową kwarantanną bądź poddana hospitalizacji i w związku z tym nie jest w stanie w ogóle podpisać pełnomocnictwa - wówczas nie ma możliwości udzielić pełnomocnictwa do prowadzenia sprawy pełnomocnikowi profesjonalnemu z uwagi na niemożność złożenia własnoręcznego podpisu pod pełnomocnictwem (Kastelik-Smaza 2020, 30-41). Owszem, przedstawiciele doktryny zwracają uwagę, że podpis własnoręczny mógłby zostać zastąpiony podpisem elektronicznym, ale należy pamiętać, że taki podpis nie jest dostatecznie rozpowszechniony, wobec czego nie można oczekiwać od osoby objętej kwarantanną podpisania pełnomocnictwa kwalifikowanym podpisem elektronicznym (Gołaczyński 2020, 4).

Problematyczna natomiast jest sytuacja, gdy strona domaga się zawieszenia biegu terminu przedawnienia powołując się na COVID-19 jako siłę wyższą, podczas gdy przebywa na swego rodzaju ,prywatnej kwarantannie”. Chodzi tu o sytuację, gdy dana osoba nie opuszcza miejsca zamieszkania wyłącznie z powodu własnej obawy przed zakażeniem, podczas gdy nie została objęta przymusową kwarantanną mocą decyzji Sanepidu (Partyk 2020, 42-52). W takim przypadku możliwość powołania się na art. 121 pkt 4 k.c. może być wątpliwa - tego typu kwestie trzeba będzie rozstrzygać w każdym przypadku indywidualnie. To od okoliczności danego przypadku będzie zależała możliwość zastosowania zawieszenia biegu terminu przedawnienia z art. 121 pkt 4 k.c., dla ustalenia której pomocne może się okazać np. zaświadczenie lekarskie, wskazujące na zły 
stan zdrowia danej osoby, z jednoczesnym zaleceniem, ażeby osoba przebywająca na takiej ,prywatnej kwarantannie” nie kontaktowała się z innymi w czasie pandemii (Partyk 2020, 42-52). Taka okoliczność może bowiem uzasadniać zaistnienie siły wyższej, uniemożliwiającej dochodzenie roszczeń przed sądem.

Należy również rozważyć sytuację, gdy to pełnomocnik strony jest poddany obowiązkowej kwarantannie. Czy taki przypadek może być traktowany jako siła wyższa uzasadniająca zawieszenie biegu terminu przedawnienia w myśl art. 121 pkt 4 k.c.? Otóż, odpowiedź na to pytanie będzie podobna, jak w przypadku osoby działającej samodzielnie. Tutaj również każdą sytuację będzie trzeba rozpatrywać indywidualnie. Wskazuje się bowiem, że zarażenie pełnomocnika strony koronawirusem $i$ jego hospitalizacja nie zawsze musi być postrzegana jako przypadek siły wyższej, zwłaszcza gdy w związku z przedłużeniem terminu na składanie pisma strona miała wystarczająco dużo czasu na to, by udzielić pełnomocnictwa innemu profesjonaliście, by to za jego pośrednictwem złożyć pismo i zająć stanowisko w sprawie (Kastelik-Smaza 2020, 30-41). Takie przedłużenie terminów zostało przewidziane w ramach Unii Europejskiej przez TSUE w stosunku do toczących się postępowań i związanych z nimi czynności procesowych (Trybunał Sprawiedliwości Unii Europejskiej 2020). Jak podkreśla TSUE, nie każdy przypadek niedochowania terminu może być traktowany jako następstwo siły wyższej - konieczne jest bowiem zaistnienie nie tylko elementu obiektywnego, ale także elementu subiektywnego, a więc istotne jest, aby strona podjęła wszelkie środki właściwe do tego, by zabezpieczyć się przed następstwami nadzwyczajnego zdarzenia, a zwłaszcza, by dołożyła należytej staranności w nadzorowaniu przebiegu postępowania, w szczególności, by dochować zastrzeżonych terminów (Kastelik-Smaza 2020, 30-41). Podobne rozważania możemy przenieść na grunt prawa polskiego. Skoro siłę wyższą traktuje się jako zjawisko nadzwyczajne, niemożliwe do przewidzenia i niemożliwe do zapobieżenia, to trzeba w każdym przypadku dokładnie przeanalizować, czy strona miała możliwość zapobieżenia skutkom pandemii, chociażby przez możliwość ustanowienia nowego pełnomocnika, czy nie. Może być to bowiem decydujące w kontekście zawieszenia biegu terminu przedawnienia $\mathrm{w}$ trybie art. $121 \mathrm{pkt} 4$ k.c.

Warto również zwrócić uwagę na możliwość składnia pism drogą elektroniczną, zagwarantowaną zarówno przez niektóre polskie sądy, jak i TSUE. Jest to dobra alternatywa dla osób, które z uwagi na przymusową kwarantannę bądź hospitalizację nie mogą złożyć pisma przez operatora pocztowego bądź w biurze podawczym sądu. Należy jednak pamiętać, że mimo iż postęp technologiczny w dzisiejszych czasach jest ogromny, to wciąż są ludzie, którzy nie mają Internetu bądź nie potrafią korzystać z portali umożliwiających wnoszenie pism drogą elektroniczną. Wobec tego, nawet jeżeli dana osoba miała złożyć pismo do sądu, w którym przewidziano możliwość wnoszenia pism przez Internet, to jeszcze nie uzasadnia, w moim przekonaniu, uznania, że w jej przypadku w żadnym razie nie można mówić o sile wyższej. Otóż tutaj, podobnie, jak przy każdej analizowanej 
wcześniej kwestii, kluczowe będzie zbadanie indywidualnych okoliczności każdego konkretnego przypadku. Dlatego też podkreśla się, że uzasadnieniem dla odmowy zastosowania zawieszenia biegu terminu przedawnienia z powodu siły wyższej nie może być sam fakt wydania przez prezesów niektórych sądów zarządzeń, dających możliwość wnoszenia pism procesowych drogą elektroniczną, zwłaszcza jeżeli tego typu zarządzenia stanowią raczej rozwiązania wyjątkowe w skali całego kraju (Strus-Wołos 2020).

Podsumowując, widać wyraźnie, iż również kwestia zawieszenia biegu terminów przedawnienia z powodu siły wyższej, przewidziana w art. 121 pkt 4 k.c., jest problematyczna. Samo powołanie się na istnienie pandemii na pewno nie wystarczy, by móc zastosować ww. przepis. Konieczne jest również zaistnienie pewnych dodatkowych okoliczności, które będą wskazywać, iż dana osoba faktycznie nie mogła dochodzić swoich roszczeń, a takimi okolicznościami może być przede wszystkim przebywanie na przymusowej kwarantannie i to przed ustanowieniem pełnomocnika, hospitalizacja związana z zakażeniem koronawirusem czy wprowadzony stosownym rozporządzeniem zakaz przemieszczania się (z pewnymi wyjątkami). Należy jednak pamiętać, że sama obawa przez zarażeniem wirusem SAR-CoV-2 i związana z tym ,prywatna kwarantanna”, niewynikająca z decyzji Sanepidu, raczej nie będzie uzasadniać zastosowania art. 121 pkt 4 k.c., chyba że podmiot zainteresowany przedstawi stosowne zaświadczenie lekarskie, z którego wynikać będzie, że jest on w grupie zwiększonego ryzyka ciężkiego przebiegu choroby w razie zakażenia, a co za tym idzie - zaleca mu się nieopuszczanie miejsca zamieszkania i unikanie spotkań z innymi ludźmi.

\section{PODSUMOWANIE}

W świetle przeprowadzonych w niniejszym opracowaniu rozważań należy przyjąć, że traktowanie pandemii COVID-19 jako siły wyższej nie jest tak oczywiste, jak mogło by się wydawać. O ile bowiem należy stwierdzić, że obiektywnie pandemia koronawirusa spełnia przesłanki siły wyższej, o tyle różnie sytuacja może wyglądać, odnosząc się do kwestii niemożliwości jej zapobieżenia czy na gruncie prawa europejskiego do kwestii dołożenia należytej staranności przez osobę powołującą się na pandemię koronawirusa jako siłę wyższą, która to należyta staranność ma przejawiać się w podjęciu wszelkich właściwych środków chroniących przed skutkami tego nadzwyczajnego zjawiska, jakim w tym przypadku jest trwająca pandemia. Na tej podstawie widać więc wyraźnie, że każda sprawa, w której pojawi się odwołanie do pandemii COVID-19 jako siły wyższej uzasadniającej czy to zwolnienie z odpowiedzialności z tytułu niewykonania zobowiązania, czy to zawieszenie biegu terminu przedawnienia na podstawie art. $121 \mathrm{pkt}$ 4 k.c., musi być rozpatrywana indywidualnie, z uwzględnieniem konkretnych okoliczności faktycznych danej sprawy. 
Pandemia COVID-19 oraz będące konsekwencją jej rozprzestrzeniania się obostrzenia i ograniczenia wprowadzane przez władzę, zwłaszcza ograniczenia przemieszczania się czy prowadzenia działalności gospodarczej, niewątpliwie wpłynęły na obrót gospodarczy, w szczególności w kontekście wywiązywania się przez strony różnego rodzaju zobowiązań umownych z wynikających z tych zobowiązań obowiązków, prowadząc do nienależytego ich wykonania bądź nawet ich niewykonania w ogóle. Co więcej, nie ulega wątpliwości, że pandemia w wielu przypadkach stanęła obywatelom na drodze do dochodzenia przez nich swych praw przed sądem poprzez uniemożliwienie im złożenia pisma w odpowiednim terminie czy stawienia się na rozprawie z uwagi na ograniczoną działalność sądów, wprowadzane ograniczenia w przemieszczaniu się czy niemożność opuszczenia miejsca zamieszkania lub miejsca stałego pobytu ze względu na obowiązek poddania się przymusowej kwarantannie w związku z zakażeniem bądź podejrzeniem zakażenia wirusem SARS-CoV-2.

Pomimo tych wyraźnych, negatywnych skutków, jakie przyniosła ze sobą pandemia COVID-19 w sferze prawnej i gospodarczej, nie można jednak, biorąc pod uwagę wyniki niniejszych rozważań, mówić o uniwersalnym uznawaniu pandemii koronawirusa za siłę wyższą, gdyż sam fakt jej wystąpienia nie jest wystarczający do powołania się na siłę wyższą - konieczne jest również wykazanie, że pandemii i wynikającym z niej skutkom nie dało się zapobiec, co będzie oczywiście ciążyło na podmiocie, który na tę siłę wyższą się powołuje.

\section{BIBLIOGRAFIA}

Cempura, Aleksandra. Anna Kasolik. 2020. „16. Siła wyższa”. W Metodyka sporządzania umów gospodarczych. Red. Aleksandra Cempura, Anna Kasolik. Warszawa: LexisNexis.

CIC Kancelaria. Bogna Czajka-Marchlewicz. Dorota Dorska. 2011. „8.6 Siła wyższa”. W Umowy w procesie budowlanym. Red. CIC Kancelaria, Bogna Czajka-Marchlewicz, Dorota Dorska. Warszawa: LEX.

Gniezdzia, Robert. 2020. Wplyw koronawirusa na umowy z kontrahentami. LEX/el.

Gołaczyński, Jacek. 2020. „Przedawnienie roszczeń majątkowych i terminy zawite w okresie po ogłoszeniu stanu epidemii związanej z COVID-19”. Monitor Prawniczy 8: 397.

Grochalski, Stefan Marian. 2012. Granice państwa jako granice jurysdykcji w Unii Europejskiej. Dąbrowa Górnicza: Wyższa Szkoła Biznesu.

Kania, Marcin. 2020. Bieg terminu przedawnienia roszczeń w dobie epidemii. Lex/el.

Kastelik-Smaza, Agnieszka. 2020. „Epidemia COVID-19 jako siła wyższa w świetle orzecznictwa Trybunału Sprawiedliwości Unii Europejskiej”. Europejski Przegląd Sąowy 5: 30-41.

Ostałowski, Jakub. 2020. Szczególne rozwiązania wspierające realizację programów operacyjnych w zwiazku z wystapieniem COVID-19 w 2020 r. Komentarz. LEX/el.

Pałdyna, Tomasz. 2012. Przedawnienie w polskim prawie cywilnym. Warszawa: LexisNexis.

Parafianowicz, Joanna. 2020. Kodeks postepowania cywilnego. Postępowanie procesowe. Komentarz. Red. Olga Maria Piaskowska. Warszawa: LEX/el.

Partyk, Aleksandra. 2020. „Epidemia (COVID-19) a tok postępowań cywilnych i sądowoadministracyjnych". Przeglad Prawa Publicznego 5: 42-52. 
Pyziak-Szafnicka, Małgorzata. 2014. Kodeks cywilny. Komentarz. Część ogólna. Red. Paweł Księżak. Warszawa: Wolters Kluwer Polska.

Rawa, Beata. 2020. „1.1. Wpływ COVID-19 na już zawarte umowy współpracy”. W Ceny transferowe w czasie kryzysu. Red. Jarosław F. Mika. Warszawa: Wolters Kluwer Polska.

Sendrowski, Paweł. 2020. Siła wyższa w stosunkach gospodarczych ( $w$ tym w ramach zamówień publicznych). LEX/el.

Sikora, Alicja. 2011. Sankcje finansowe w razie niewykonania wyroków Trybunału Sprawiedliwości Unii Europejskiej. Warszawa: Wolters Kluwer Polska.

Stradomska-Balcerzyk, Katarzyna. 2020. „Kształtowanie cywilnoprawnych stosunków zobowiązaniowych w świetle ustawodawstwa epidemicznego". Monitor Prawniczy 17: 898.

Strus-Wołos, Monika. 2020. „Stan epidemii wywołanej przez wirus SARS-COV-2 (COVID-19) jako siła wyższa uzasadniająca zawieszenie biegu terminów przedawnienia roszczeń w rozumieniu art. 121 pkt 4 k.c." Glos Prawa. Przegląd Prawniczy Allerhanda 3: 28-36.

Trybunał Sprawiedliwości Unii Europejskiej. 2020. „Dostosowanie działalności sądowniczej Trybunału Sprawiedliwości z uwagi na pandemię koronawirusa COVID-19”. https://curia. europa.eu/jcms/jcms/P_97552/p1/ [dostęp: 5.05.2020].

Zoll, Fryderyk Stanisław. 2020. „Zasady ELI (European Law Institute) na czas kryzysu COVID-19”. Transformacje Prawa Prywatnego 3: 247-256.

\section{Akty prawne}

Ustawa z dnia 23 kwietnia 1964 r. - Kodeks cywilny (tekst jedn.: Dz.U. 2020, poz. 1740).

Ustawa z dnia 24 listopada 2017 r. o imprezach turystycznych i powiązanych usługach turystycznych (tekst jedn.: Dz.U. 2020, poz. 2139).

Ustawa z dnia 2 marca 2020 r. o szczególnych rozwiązaniach związanych z zapobieganiem, przeciwdziałaniem i zwalczaniem COVID-19, innych chorób zakaźnych oraz wywołanych nimi sytuacji kryzysowych (tekst jedn.: Dz.U. 2020, poz. 1842 ze zm.).

Ustawa z dnia 31 marca 2020 r. o zmianie ustawy o szczególnych rozwiązaniach związanych z zapobieganiem, przeciwdziałaniem i zwalczaniem COVID-19, innych chorób zakaźnych oraz wywołanych nimi sytuacji kryzysowych oraz niektórych innych ustaw (Dz.U. 2020, poz. 568).

Rozporządzenie Rady Ministrów z dnia 31 marca 2020 r. w sprawie ustanowienia określonych ograniczeń, nakazów i zakazów w związku z wystąpieniem stanu epidemii (Dz.U. 2020, poz. 566).

Rozporządzenie Rady Ministrów z dnia 10 kwietnia 2020 r. w sprawie ustanowienia określonych ograniczeń, nakazów i zakazów w związku z wystąpieniem stanu epidemii (Dz.U. 2020, poz. 658).

Rozporządzenie Rady Ministrów z dnia 2 maja 2020 r. w sprawie ustanowienia określonych ograniczeń, nakazów i zakazów w związku z wystąpieniem stanu epidemii (Dz.U. 2020, poz. 792).

\section{Orzecznictwo}

Postanowienie TSUE z dnia 18 stycznia 2005 r., C-325/03 P, José Luis Zuazaga Meabe v. Urzad Harmonizacji Rynku Wewnętrznego (znaki towarowe $i$ wzory przemysłowe), Dz.U.UE.C.2005.106.11/1.

Wyrok Sądu Apelacyjnego w Lublinie z dnia 19 listopada 2019 r. (III APa 15/19, LEX Nr 2750252). Wyrok Sądu Apelacyjnego w Warszawie z dnia 28 maja 2014 r. (I ACa 1775/13, LEX Nr 1489180). Wyrok SN z dnia 21 maja 2019 r., IV CSK 129/18, LEX Nr 2690186.

Wyrok Krajowej Izby Odwoławczej z dnia 10 czerwca 2020 r., KIO 631/20, LEX Nr 3029206. 
Inne

Rządowy projekt ustawy o zmianie ustawy o szczególnych rozwiązaniach związanych z zapobieganiem, przeciwdziałaniem i zwalczaniem COVID-19, innych chorób zakaźnych oraz wywołanych nimi sytuacji kryzysowych oraz niektórych innych ustaw (Druk Nr 299). https://www.sejm.gov.pl/sejm9.nsf/druk.xsp?nr=299

Opinia rzecznika generalnego Jacobs przedstawiona w dniu 16 marca 2000 r. Komisja Wspólnot Europejskich przeciwko Królestwu Belgii. Uchybienie zobowiązaniom Państwa Członkowskiego. Sprawa C-236/99. ECLI identifier: ECLI:EU:C:2000:141. 